THE FOUNTAIN OF KNOWLEDGE 
INNOVATION AND TECHNOLOGY IN THE WORLD ECONOMY

MARTIN KENNEY, Editor

University of California, Davis, and Berkeley Roundtable on the International Economy

Other titles in the series:

MARTIN KENNEY AND DAVID C. MOWERY, EDS.

Public Universities and Regional Growth: Insights from the University

of California

MARY LINDENSTEIN WALSHOK AND ABRAHAM J. SHRAGGE

Invention and Reinvention: The Evolution of San Diego's Innovation Economy

JOHN ZYSMAN AND MARK HUBERTY, EDS.

Can Green Sustain Growth?

From the Religion to the Reality of Sustainable Prosperity

ISRAEL DRORI, SHMUEL ELLIS, AND ZUR SHAPIRA

The Evolution of a New Industry: A Genealogical Approach

JEFFREY L. FUNK

Technology Change and the Rise of New Industries

KAYE HUSBANDS FEALING, JULIA I. LANE, JOHN H. MARBURGER III, AND STEPHANIE S. SHIPP, EDS.

The Science of Science Policy: A Handbook

JERALD HAGE

Restoring the Innovative Edge:

Driving the Evolution of Science and Technology

SALLY H. CLARKE, NAOMI R. LAMOREAUX, AND STEVEN W. USSELMAN, EDS.

The Challenge of Remaining Innovative:

Insights from Twentieth-Century American Business

JOHN ZYSMAN AND ABRAHAM NEWMAN, EDS.

How Revolutionary Was the Digital Revolution?

National Responses, Market Transitions, and Global Technology 
MARTIN FRANSMAN, ED.

Global Broadband Battles: Why the U.S.

and Europe Lag While Asia Leads

DAVID C. MOWERY, RICHARD R. NELSON, BHAVEN N. SAMPAT, AND ARVIDS A. ZIEDONIS

Ivory Tower and Industrial Innovation: University-Industry Technology Transfer Before and After the Bayh-Doyle Act

MARTIN KENNEY AND RICHARD FLORIDA, EDS.

Locating Global Advantage: Industry Dynamics in the International Economy

GARY FIELDS

Territories of Profit: Communications, Capitalist Development, and the Innovative Enterprises of G. F. Swift and Dell Computer

URS VON BURG

The Triumph of Ethernet: Technological Communities and the Battle for the LAN Standard 



\section{The Fountain of Knowledge}

THE ROLE OF UNIVERSITIES

IN ECONOMIC DEVELOPMENT

Shiri M. Breznitz

STANFORD BUSINESS BOOKS

An Imprint of Stanford University Press

Stanford, California 
Stanford University Press

Stanford, California

(C) 2014 by the Board of Trustees of the Leland Stanford Junior University. All rights reserved.

No part of this book may be reproduced or transmitted in any form or by any means, electronic or mechanical, including photocopying and recording, or in any information storage or retrieval system without the prior written permission of Stanford University Press.

Special discounts for bulk quantities of Stanford Business Books are available to corporations, professional associations, and other organizations. For details and discount information, contact the special sales department of Stanford University Press.

Tel: (650) 736-I782, Fax: (650) 736-1784

Printed in the United States of America on acid-free, archival-quality paper

Library of Congress Cataloging-in-Publication Data

Breznitz, Shiri M., author.

The fountain of knowledge : the role of universities in economic development / Shiri M. Breznitz.

pages $\mathrm{cm}-$ (Innovation and technology in the world economy)

Includes bibliographical references and index.

ISBN 978-0-8047-896I-5 (cloth : alk. paper)

I. Universities and colleges-Economic aspects-Case studies.

2. Technology transfer-Case studies. 3. Biotechnology-Technology transfer-Case studies. 4. Academic-industrial collaborationEconomic aspects-Case studies. 5. Yale University. 6. University of Cambridge. I. Title. II. Series: Innovation and technology in the world economy.

$$
\begin{aligned}
& \text { LC67.6.B72 } 20 \mathrm{I} 4 \\
& 338.4^{\prime} 3378-\mathrm{dc} 23
\end{aligned}
$$

ISBN 978-0-8047-9192-2 (electronic)

Typeset by Newgen in Io/13 Galliard 
To Danny, the wind beneath my wings 
